\title{
ANALISIS PERBANDINGAN KINERJA KEUANGAN ANTARA BANK CENTRAL ASIA DAN BANK NEGARA INDONESIA BERDASARKAN METODE ECONOMIC VALUE ADDED (EVA) DAN MARKET VALUEADDED (MVA) PADA TAHUN 2011-2015
}

\author{
Jack Tri Saputra, Aminar Sutra Dewi \\ Sekolah Tinggi Ilmu Ekonomi KBP \\ jacktrisaputra@yahoo.com
}

\begin{abstract}
This study aims to determine the performance of Bank BCA and Bank BNI using EVA and MVA during the years 2011 to 2015. The study was categorized as a comparative descriptive study. The author chose a sample of a population's financial statements, issued by PT Bank Central Asia Tbk and PT Bank Negara Indonesia Tbk. The data used are secondary data with engineering documentation. Data analysis method used is Independent Sample T-test. The results showed that there is no difference in financial performance by using thr method EVA and MVA at the Bank BCA with the Bank BNI. From result of the data processing found value $t$ tabel $>t$ hitung that is 2,306 > 1,549 for variables EVA and 2,306 > -2,024 for variables MVA.
\end{abstract}

Keyword : Economic Value Added, Market Value Added, Financial Performance.

\section{PENDAHULUAN}

Kinerja keuangan merupakan gambaran prestasi yang dicapai perusahaan dalam kegiatan operasionalnya baik menyangkut aspek keuangan, aspek pemasaran, aspek penghimpunan dana dan penyaluran dana, aspek teknologi, maupun aspek sumber daya manusianya. Untuk mengetahui kinerja keuangan yang telah dicapai perlu dilakukan analisis terhadap laporan keuangan perusahaan, untuk mengetahui kekuatan dan kelemahan perusahaan dalam bidang keuangan, yang biasanya perusahaan menggunakanan analisis rasio keuangan (Van Horne dan HeruSutejo, 2005).

Menurut Horne (2005) "Rasio keuangan adalah alat yang digunakan untuk menganalisis kondisi keuangan dan kinerja perusahaan".Meskipun analisis rasio keuangan digunakan oleh investor sebagai alat pengukur konvensional, analisis rasio tersebut mempunyai kelemahan utama, yaitu mengabaikan adanya biaya modal sehingga sulit untuk mengetahui apakah suatu perusahaan telah berhasil menciptakan suatu nilai atau belum. Oleh karena itu, pada tahun 1989, Konsultan Stern Steward Management Service di Amerika Serikat memperkenalkan konsep Economic Value Added (EVA) dan Market Value Added (MVA) sebagai alat ukur 
kinerja keuangan dan pasar untuk mengatasi kelemahan dari rasio keuangan (Setyarini, 2010).

Menurut Wijaya dan Tjun (2009) Economic Value Added adalah indikator internal yang mengukur kekayaan pemegang saham suatu perusahaan dalam jangka waktu tertentu.EVA mengukur seberapa efisien perusahaan menggunakan modalnya untuk menciptakan nilai tambah ekonomis. Nilai tambah ekonomis tercipta jika perusahaan menghasilkan return on total capital yang melebihi cost of capital. EVA positif berarti perusahaan memeroleh laba karena tingkat pengembalian melebihi biaya modalnya, sehingga perusahaan yang memperoleh laba akan membagikan sebagian labanya sebagai dividen kepada investor. Semakin tinggi laba yang diperolehperusahaan, maka semakin tinggi pula dividen yang diperoleh investor. Semakin tinggi capital gain dan dividen, maka Return saham juga akan semakin tinggi.

Selain Economic Value Added (EVA) digunakan juga Market Value Added (MVA) yang berfungsi sebagai pengukur kinerja keuangan. Pengukuran MVA menilai dampak tindakan manajer atas kemakmuran pemegang sahamnya sejak perusahaan tersebut berdiri. Menurut Brigham (2001) dalam Kartini dan Hermawan (2008), kekayaan pemegang saham akan menjadi maksimal dengan memaksimalkan perbedaan antara nilai pasar ekuitas perusahaan dan jumlah modal ekuitas yang diinvestasikan investor, perbedaan inilah yang disebut Market Value Added (MVA).

Tabel 1

Hasil perhitungan EVA dan MVA Bank BCA dengan Bank BNI Periode 2011 sampai dengan 2015 (dalam jutaan)

\begin{tabular}{|c|c|c|}
\hline Bank & EVA & MVA \\
\hline BBCA & 3.592 .334 .608 & 237.862 .831 .296 \\
\hline BBNI & 2.304 .794 .823 & 18.765 .997 .766 \\
\hline
\end{tabular}

Sumber: Laporan keuangan BI dan data sudah diolah

Berdasarkan tabel 1 dapat diketahui bahwa EVAdan MVAbank BCA berfluktuasi atau bernilai positif. Dimana nilai EVA bank BCA sebesar Rp. 3.592.334.608 dan MVA sebesar Rp.237.862.831.296, Hal ini mengindikasikan bahwa bank BCA dapat menciptakan nilai tambah ekonomis bagi perusahaan dan berhasil meningkatkan nilai modal yang telah diinvestasikan oleh pemegang saham. Sedangkan bank BNI EVA dan MVA nya juga berfluktuasi, tetapi memiiki nilai EVAsebesar Rp. 2.304.794.823 dan MVA sebesar Rp. 18.765.997.766. Jika dibandingkan dengan pencapaian EVA dan MVA pada bank BCA, maka penciptaan nilai tambah perusahaan sangat kecil, Meski demikian nilai EVA dan MVA bank BNI yang bernilai positif memberi isyarat bahwa kinerjaperushaan mampu memberikan nilai tambah bagi pemilik maupun pemegang saham.

Rumusan Masalah

1. Apakah Economic Value Added (EVA) Bank BCA berbeda dengan Economic Value Added (EVA) Bank BNI pada tahun 2011-2015? 
2. Apakah Market Value Added (MVA) Bank BCA berbeda dengan Market Value Added (MVA) Bank BNI pada tahun 2011-2015?

Tujuan Penelitian

1. Mengetahui hasil perbedaan Economic Value Added (EVA) Bank BCA dengan Economic Value Added (EVA) Bank BNI pada tahun 2011-2015.

2. Mengetahui hasil perbedaan Market Value Added (MVA) Bank BCA dengan Market Value Added (MVA) Bank BNI pada tahun 2011-2015.

\section{LANDASAN TEORI}

\section{Pengertian Laporan Keuangan}

Laporan keuangan adalah daftar yang disusun oleh akuntan pada akhir untuk suatu perushaan.Kedua daftar itu adalah neraca atau daftar posisi keuangan dan daftar pendapatan atau daftar laba rugi. Pada waktu akhir-akhir ini sudah menjadi kebiasaan bagi perseroan-perseroan untuk menambahkan daftar ketiga yaitu daftar surplus atau daftar laba yang tidak dibagikan (laba ditahan), (Munawir,2004).

\section{Tujuan Laporan Keuangan}

Tujuan laporan keuangan menurut Standar Akuntansi yang dikutip oleh Sawir (2005: 2 tujuan laporan keuangan adalah sebagai berikut :

a. Menyediakan informasi yang menyangkut posisi keuangan pada suatu perusahaan sehingga memberi manfaat bagi sejumlah besar pemakai dalam pengambilan keputusan ekonomi.

b. Laporan keuangan disusun untuk memenuhi kebutuhan bersama oleh sebagian besar pemakainya, yang secara umum mengambarkan pengaruh dari kejadian masa lalu.

c. Laporan keuangan juga menunjukan apa yang dilakukan manajemen atau mempertanggung jawaban manajemen atas sumber daya yang dipercayakan kepadanya.

\section{Kinerja Keuangan}

Kinerja atau prestasi kerja berasal dari pengertian performance.Kinerja adalah tentang melakukan pekerjaan dan hasil yang dicapai dari pekerjaan tersebut.Kinerja merupakan hasil pekerjaan yang mempunyai hubungan kuat dengan tujuan strategis organisasi, kepuasan konsumen dan memberikan kontribusi ekonomi. Dalam kegiatan ekonomi bisnis bank umum dapat dikatakan berhasil jika dapat mencapai sasaran bisnis yang telah ditentukan

\section{Tujuan Penilaian Kinerja Keuangan}

Tujuan penilaian kinerja perusahaan menurut Munawir dalam bukunya "Analisa Laporan Keuangan" (2000:31) adalah sebagai berikut:

a. Untuk mengetahui tingkat likuiditas, yaitu kemampuan perusahaan untuk memperoleh kewajiban keuangannya yang harus segera dipenuhi atau kemampuan perusahaan untuk memenuhi keuangannya pada saat ditagih.

b. Untuk mengetahui tingkat solvabilitas, yaitu kemampuan perusahaan untuk memenuhi kewajiban keuangannya apabila perusahaan tersebut dilikuidasi baik kewajiban keuangan jangka pendek maupun jangka panjang. 
c. Untuk mengetahui tingkat rentabilitas atau profitabilitas, yaitu menunjukkan kemampuan perusahaan untuk menghasilkan laba selama periode tertentu.

Tahap-tahap Dalam Menganalisis Kinerja Keuangan

Fahmi (2011:3) ada 3 tahap dalam menganalisis kinerja keuangan yaitu:

a. Melakukan review terhadap data laporan keuangan.

b. Melalukan Perhitungan.

c. Melakukan perbandingan terhadap hasil hitungan yang telah diperoleh dengan hasil hitungan dari berbagai perusahan lainnya.

\section{Economic Value Added (EVA)}

EVA adalah nilia yang ditambahkan oleh manajemen kepada pemegang saham salama satu tahun tertentu. Sebagai pencetus, Steward (1991) dalam Wijaya \& Tjun (20099) mendefinisikan EVA sebagai berikut: "The one performance measure to account properly for all of the ways in which corporate value may be added or lost is Economic Value Added (EVA). EVA is the residual incomemeasure that substracts the cost of capital from the operating profit generated in the bussines. "(Brigham dan Houston, 2006).

\section{Perhitungan Economic Value Added (EVA)}

Dalam menghitung EVA diperlukan tiga indicator utama yaitu pendapatan operasi setelah pajak (NOPAT), Biaya modal yang diinvestasikan (Invested Capital), biaya rata-rata tertimbang (WACC), Pendapatan hasil bersih setelah pajak menggambarkan hasil penciptaan nilai (Value) pada perusahaan, sedangkan biaya modal diartikan sebagai pengorbanan yang dikeluarkan untuk penciptaan nilai (Value) tersebut. Stewart merumuskan EVA sebagai berikut:

\section{EVA $=$ NOPAT $-($ WACC $x$ Invested Capital $)$}

Dimana :

NOPAT : Laba operasi setelah pajak (Net Operating Profit After Tax)

WACC : Biaya ekuitas rata-rata tertimbang

InvestedCapital :Besarnyacapital yang diinvestasikan dalam perushaan.

\section{Ukuran Kinerja Economic Value Added (EVA)}

Rudianto (2006) menjelaskan hasil penilain kinerja suatu perusahaan dengan menggunakan EVA dapat dikelompokan menjadi tiga kategori yang berbeda, yaitu:

a. Nilai EVA $>0$ atau EVA bernilai positif

Pada posisi ini berarti manajemen perusahaan telah berhasil menciptakan nilai tambah ekonimis bagi perusahaan.

b. Nilai $\mathrm{EVA}=0$

Pada posisi ini berarti manajemen perushaaan berada dalam titik impas.Perusahaan tidak mengalami kemunduran tetapi sekaligus tidak mengalami kemajuan secara ekomoni.

c. Nilai EVA < 0 atau bernilai negative

Pada posisi ini berarti tidak terjadi proses penambahan nilai ekomonis bagi perusahaan, dalam arti laba yang dihasilkan tidak dapat memenuhi harapan para pemegang saham perusahaan (investor). 


\section{Market Value Added (MVA)}

Market Value Added merupakan suatu pengukuran kinerja yang teat untuk menilai sukses tidaknya perusahaan dalam menciptakan kekayaan bagi pemiliknya". Jadi kekayaan atau kejesahteraan pemilik perusahaan akan bertambah bila MVA bertambah.

\section{Perhitungan Market Value Added (MVA)}

Nilai tamabah pasar atau MVA adalah perbedaan antara nilai pasar saham peusahaan dengan jumlah ekuitas modal investor yang telah diberikan, (Brigham, 2006 : 68). Dapat dirumuskan sebagai berikut:

\section{MVA = Market Value of Equity - Total ekuitas}

\section{Ukuran Kinerja Economic Value Added (EVA)}

a. Jika Market Value Added (MVA) > 0, bernilai positif, perusahaan berhasil meningkatkan nilai modal yang telah diinvestasikan oleh pemegang saham.

b. Jika Maket Value Added (MVA) < 0, bernilai negative, perusahaan tidak berhasil meningkatkan nilai modal yang telah diinvestasikan oleh pemegang saham (Young dan O’Byrne, 2001).

\section{METODOLOGI PENELITIAN \\ Jenis Penelitian}

Jenis dan pendekatan yang digunakan dalam penelitian ini adalah kuantitatif.Penelitian kuantitatif adalah suatu penelitian yang didasari oleh falsafah positivisme yaitu ilmu yang valid, ilmu yang di bangun dari empiris, teramati, terukur, menggunakan logika matematika dan membuat generalisasi atas rata-rata.(Hidayat dan Sedarmayanti: 2002: 35). Penelitian ini menggunakan penelitian kuantitatif, karena penelitian ini bersifat menganalisa laporan keuangan pada Bank Central Asia dan Bank Negara Indonesia dan menafsirkan hasilnya dalam bentuk angka-angka.

\section{Populasi dan Sampel}

Menurut Sugiyono (2014:115) populasi adalah wilayah generalisasi yang terdiri atas obyek/subyek yang mempunyai kualitas dan karakteristik tertentu yang ditetapkan oleh peneliti untuk dipelajari dan kemudian ditarik kesimpulannya.Data yang digunakandalampenelitianiniadalah data sekunder dengan merujuk pada laporan keuangan Bank Central Asia dan Bank Negara Indonesia tahun 2011-2015.

\section{Sampel}

Sampel merupakan bagian dari jumlah dan karakteristik yang dimiliki populasitersebut (Sugiyono, 2009). Teknik yang digunakan dalam pengambilan sampel menggunakan metode purposive sampling, yaitu metode penentuan sampel dengan pertimbangan tertentu (Sugiyono, 2009), dengan menggunakan karakteristik sebagai berikut :

a. Perusahaan tersebut terdaftardalam Bursa Efek Indonesia selama periode penelitian (2011-2015)

b. Perusahaan tersebut menerbitkan laporan keuangan tahunan secara berturutturut selama periode penelitian dan dapat diakses oleh publik. 
c. Perusahan tersebut masuk dalam LQ45 selama periode penelitian (20112015).

\section{TeknikPengumpulan Data}

Jenis data yang digunakan adalah data sekunder berupa laporan keuangan tahunan pada Bank BCA dan Bank BNI dalam kurun waktu 5 tahun terakhir (2011-2015) dan data tersebut sudah diolah dan terdokumentasi dari perusahaan, seperti laporan keuangan yaitu Laporan neraca, Laporan laba rugi dan Harga saham yang diakses melalui situs resmi www.bi.co.id, www.idx.co.id, dan www.sahamok.co.id.

\section{Teknik Analisa Data}

Teknik analisis data yang digunakan dalam penelitian ini adalah metode analisis stastik. Analisis data yang digunakan dengan menggunakan SPSS, yang mana analisis teknik data yang digunakan oleh peniliti adalah :

\section{Uji Normalitas}

Uji normalitas adalah untuk melihat apakah nilai residual terdistribusi normal atau tidak.Model regresi yang baik adalah memiliki nilai residual yang terdistribusi normal.Jadi uji normalitas bukan dilakukan pada masing-masing variabel, tetapi pada nilai residualnya (Kurniawan, 2014:156).

\section{Uji Independent Sample T-tes}

Untuk mengetahui perbedaan rata-rata dua sampel yang saling bebas, melalui pengujian ini dapat diketahui signifikan perbedaan rata-rata dua kelompok sampel yang saling tidak berhubungan.Uji Independent Sample T-test adalah dengan membandingkan $F_{\text {hitung }}$ dengan $F_{\text {tabel }}$ pada $(\alpha)=5 \%(0.05)$.

\section{HASIL PENELITIAN DAN PEMBAHASAN \\ Teknik Analisa Data \\ Uji Normalitas Data}

Tabel 2

Hasil Uji Normalitas Data

\begin{tabular}{|c|c|c|c|}
\hline & & $\begin{array}{l}\text { Unstandardized } \\
\text { Residual }\end{array}$ & Kesimpulan \\
\hline EVA & $\begin{array}{l}\mathrm{N} \\
\text { Asymp. } \\
\text { tailed })\end{array}$ & $\begin{array}{r}10 \\
0.58\end{array}$ & $\begin{array}{c}\text { Data Berdistribusi } \\
\text { Normal }\end{array}$ \\
\hline MVA & $\begin{array}{l}\mathrm{N} \\
\text { Asymp. } \\
\text { tailed })\end{array}$ & $\begin{array}{r}10 \\
0,154\end{array}$ & $\begin{array}{c}\text { Data Berdistribusi } \\
\text { Normal }\end{array}$ \\
\hline
\end{tabular}

Sumber : Data Diolah

Dari hasil Uji normalitas didapat hasil menunjukkan bahwa variabel EVA dan MVA berdistribusi normal. 
Uji Independent Sample T-tes

Tabel 3

Hasil Uji Independent Sampel T-Test

\begin{tabular}{|c|c|c|c|c|c|c|c|c|c|c|}
\hline & \multicolumn{2}{|c|}{$\begin{array}{l}\text { Equality of } \\
\text { Variances }\end{array}$} & \multicolumn{7}{|c|}{ Hest for Equty of Means } \\
\hline & & \multirow[b]{2}{*}{$\mathrm{f}$} & \multirow[b]{2}{*}{ Sig. } & \multirow[b]{2}{*}{$\mathrm{t}$} & \multirow[b]{2}{*}{ df } & \multirow{2}{*}{$\begin{array}{l}\text { Sig.(2 } \\
\text { tailed) }\end{array}$} & \multirow{2}{*}{$\begin{array}{c}\text { Mean } \\
\text { Difference }\end{array}$} & \multirow{2}{*}{$\begin{array}{c}\text { Std. Error } \\
\text { Difference }\end{array}$} & \multicolumn{2}{|c|}{ Interval of the } \\
\hline & & & & & & & & & Lower & Upper \\
\hline \multirow[b]{2}{*}{ EVA } & $\begin{array}{l}\text { EquaL } \\
\text { Variances } \\
\text { Assumed }\end{array}$ & 9.322 & .116 & 1.549 & 8 & .160 & 584097208.8 & 376972087.0 & -285201983 & 1453396400 \\
\hline & $\begin{array}{l}\text { EquaL } \\
\text { Variances } \\
\text { not } \\
\text { assumed }\end{array}$ & & & 1.549 & 5.227 & .179 & 584097208.8 & 376972087.0 & -372402191 & 1540596609 \\
\hline \multirow{2}{*}{ MVA } & $\begin{array}{l}\text { EquaL } \\
\text { Variances } \\
\text { Assumed }\end{array}$ & 1.216 & .302 & -2.024 & 8 & 0.78 & -.18280 & .09031 & -.39106 & .02546 \\
\hline & $\begin{array}{l}\text { EquaL } \\
\text { Variances } \\
\text { not } \\
\text { assumed }\end{array}$ & & & -2.024 & 5.964 & 0.90 & -.18280 & .09031 & -.40411 & .03851 \\
\hline
\end{tabular}

Sumber : Data Diolah

Dari uji Independent Sample T-Test menunjukan hasil yang diperoleh untuk $t_{\text {tabel }}$ sebesar 2,306.Karenat $t_{\text {tabel }}>t_{\text {hitung }}$, yaitu 2,306>1,549 untuk EVA dan 2,306 > - 2,024 untuk MVA, maka H0diterima. Tingkat Sig. (2 tailed) $=0,160$ untuk EVA dan 0,78 untuk MVA dengan df $(n-2)=22$ sehinggatingkat Sig. (2 tailed) $>$ taraf signifikasi yaitu $0,160>0,05$ untuk EVA dan 0,78>0,05 maka H0 diterima.

\section{Hasil Perhitungang Nilai EVAdan MVA}

Hasil Perhitungan EVA Bank BCA dari tahun 2011 sampai dengan 2015 dapat dilihat pada tabel 4

Tabel 4

EVA BCA

\begin{tabular}{|c|c|c|c|}
\hline Bank & Tahun & EVA & $\begin{array}{c}\text { \% Peningkatan atau } \\
\text { Penururnan }\end{array}$ \\
\hline \multirow{3}{*}{ BCA } & 2011 & 2.147 .374 .152 & \\
\cline { 2 - 4 } & 2012 & 1.758 .958 .760 & $-18,08 \%$ \\
\cline { 2 - 4 } & 2013 & 2.283 .992 .800 & $29,84 \%$ \\
\cline { 2 - 4 } & 2014 & 3.278 .223 .548 & $43,53 \%$ \\
\cline { 2 - 4 } & 2015 & 3.592 .334 .608 & $9,58 \%$ \\
\hline
\end{tabular}

Sumber : Pengolahan Data

Berdasarkan tabel 4 dapat diketahui bahwa nilai Economic Value Added (EVA) Bank Central Asia berfluktuasi. Nilai Economic Value Added (EVA) Bank Central Asia dari tahun 2011 sampai dengan 2015 selalu bernilai positif yang berarti dari tahun 2011 sampai dengan 2015 bank BCA dapat menciptakan nilai tambah ekonomis bagi perusahaan dimana laba operasi bersih setelah pajak telah mampu untuk membayar kewajiban kepada pemegang saham. Nilai EVA bank 
BCA pada tahun 2011 mencapai Rp.2.147.374.152 akan tetapi pada tahun 2012 terjadi penurunan EVA perusahaan sebesar -18,08\% menjadi Rp.1.758.958.760. Hal tersebut disebabkan adanya peningkatan biaya modal pada tahun 2012 menjadi Rp. 17.469.658.240. Pada tahun 2015 peningkatan nilai EVA tertinggi hingga mencapai sebesar Rp.3.592.334.608. Hal ini mengindikasikan bahwa perusahaan telah mampu memberikan nilai ekonomis ke dalam perusahaan atau dengan kata lain perusahaan mampu menghasilkan nilai tambah ekonomi melalui kegiatan-kegiatan operasionalnya sehingga mampu membayar seluruh kewajibannya kepada penyedia dana (investor) dan pemerintah (pajak) tetapi juga mampu menghasilkan laba yang tinggi bagi perusahaan.

Hasil Perhitungan EVA Bank BNI dari tahun 2011 sampai dengan 2015 dapat dilihat pada tabel 5

Tabel 5

EVA BNI

\begin{tabular}{|c|c|c|c|}
\hline Bank & Tahun & EVA & $\begin{array}{c}\text { \% Peningkatan atau } \\
\text { Penururnan }\end{array}$ \\
\hline \multirow{3}{*}{ BNI } & 2011 & 1.979 .428 .494 & \\
\cline { 2 - 4 } & 2012 & 1.685 .928 .185 & $-14,82 \%$ \\
\cline { 2 - 4 } & 2013 & 1.782 .145 .890 & $5,7 \%$ \\
\cline { 2 - 4 } & 2014 & 2.388 .100 .432 & $34 \%$ \\
\cline { 2 - 4 } & 2015 & 2.304 .794 .823 & $-3,4 \%$ \\
\hline
\end{tabular}

Sumber : Pengolahan Data

Berdasarkan tabel 5 dapat diketahui bahwa nilai Economic Value Added (EVA) Bank Negara Indonesia juga berfluktuasi.Pada hasil perhitungan EVA dapat dilihat bahwa nilai EVA pada periode pengamatan selalu bernilai positif. Nilai EVA pada tahun 2011 mencapai Rp.1.979.428.494, akan tetapi pada tahun berikutnya terjadi penurunan nilai EVA mencapai $-14,82 \%$ menjadi Rp.1.685.928.185. Dan kemudian kembali meningkat ditahun berikutnya menjadi Rp.1.782.145.890 atau naik sebesar 5,7\%. Nilai EVA tertinggi pada bank BNI tejadi pada tahun 2014 sebesar Rp.2.388.100.432. Jika dibandingkan dengan pencapaian tertinggi nilai EVA bank BCA pada tahun 2015, maka penciptaan nilai tambah perusahaan bank BNI jauh lebih kecil. Hal ini ditunjukan dengan nilai EVA bank BNI pada tahun 2014 yang hanya mencapai Rp.2.388.100.432, lebih rendah jika dibandingkan dengan pencapaian nilai EVA tertinggi pada bank BCA ditahun 2015 yang mencapai Rp.3.592.334.608. Meski demikian, nilai EVA yang positif memberi isyarat bahwa kinerja perusahaan mampu memberikan nilai tambah bagi pemilik maupun para pemegang saham (investor).

Hasil perhitungan MVA Bank BCA dari tahun 2011 sampai dengan tahun 2015 dapat dilihat pada tabel 6 
Tabel 6

MVA BCA

\begin{tabular}{|c|c|c|c|}
\hline Bank & Tahun & MVA & \% Peningkatan atau Penururnan \\
\hline \multirow{3}{*}{ BCA } & 2011 & 153.302 .681 .960 & \\
\cline { 2 - 4 } & 2012 & 171.595 .411 .992 & $11,93 \%$ \\
\cline { 2 - 4 } & 2013 & 171.665 .629 .552 & $409,20 \%$ \\
\hline & 2014 & 244.340 .356 .950 & $42,33 \%$ \\
\cline { 2 - 4 } & 2015 & 237.862 .831 .296 & $-2,65 \%$ \\
\hline
\end{tabular}

Sumber : Pengolahan Data

Berdasarkan tabel 6, dapat diketahui bahwa nilai Market Value Added (MVA) bank BCA dari tahun 2011 sampai dengan 2015 selalu bernilai positif, yang berarti dari tahun 2011 sampai dengan 2015 bank BCA berhasil meningkatkan nilai modal yang telah diinvestasikan oleh penyandang dana (investor). Nilai MVA yang diperoleh bank BCA pada tahun 2011 sebesar Rp. 153.302.681.960, kemudian pada tahun 2012 terjadi peningkatan nilai MVA sebesar 11,93\% menjadi Rp. 171.595.411.992. Nilai MVA tertinggi pada bank BCA pada tahun 2014 sebesar Rp. 244.340.356.950.

Hasil perhitungan MVA Bank BCA dari tahun 2011 sampai dengan tahun 2015 dapat dilihat pada tabel 7

Tabel 7 MVA BNI

\begin{tabular}{|c|c|c|c|}
\hline Bank & Tahun & MVA & $\begin{array}{c}\text { \% Peningkatan atau } \\
\text { Penururnan }\end{array}$ \\
\hline \multirow{3}{*}{ BNI } & 2011 & 32.452 .550 .593 & \\
\cline { 2 - 4 } & 2012 & 24.676 .150 .604 & $-23,96 \%$ \\
\cline { 2 - 4 } & 2013 & 25.444 .232 .077 & $3,11 \%$ \\
\cline { 2 - 4 } & 2014 & 56.307 .940 .347 & $121,29 \%$ \\
\cline { 2 - 4 } & 2015 & 18.765 .997 .766 & $-66,67 \%$ \\
\hline
\end{tabular}

Sumber : Pengolahan Data

Berbanding terbalik dengan bank BCA, nilai MVA bank BNI mengalami ketidakstabilan. Jika pada tahun 2011 nilai MVA mencapai Rp. 32.452.550.593, maka pada tahun 2012 terjadi penurunan mencapai $-23,96 \%$ menjadi Rp.24.676.150.604. Pada tahun 2014 terjadi peningkatan yang signifikan nilai MVA bank BNI mencapai 121,29\% menjadi Rp. 56.307.940.347, dan pada tahun berikut nya nilai MVA bank BNI mengalami penurunan terendah kembali manjadi $-66,67 \%$ menjadi Rp. 18.765.997.766. Ketidakstabilan nilai MVA tersebut dikarenakan harga saham per lembar perusahaan yang cenderung menurun, sementara ekuitas perusahaan terus bertambah.Dengan nilai MVA kedua perusahaan yang positif berarti selain terdapat peningkatan kinerja, kedua perusahaan juga telah menciptakan kekyaan bagi para pemegang saham (investor). 


\section{SIMPULAN}

Berdasarkan hasil analisis dan pembahasan mengenai perbandingan kinerja keuangan antara PT Bank Central Asia dan PT Bank Negara Indonesia dengan mengunakan metode Economic Value Added (EVA) dan Market Value Added (MVA) pada tahun 2011 sampai dengan 2015, maka dapat ditarik kesimpulan yang dijelaskan sebagai berikut:

1. Tidak terdapat perbedaanEconomic Value Added (EVA) antara bank BCA dengan bank BNI. Variabel EVA menunjukkan $t_{\text {hitung }} 1,549<t_{\text {tabel }} 2,306$ dengan nilai sign 0.160 lebih besar dari tingkat alpha 0,05 .

2. Tidak terdapat perbedaanMarket Value Added (MVA) antara bank BCA dengan bank BNI. Variabel MVA menunjukkan $t_{\text {hitung }}-2,024<t_{\text {tabel }} 2,306$ dengan nilai sign 0.78 lebih besar dari tingkat alpha 0,05 .

\section{DAFTAR PUSTAKA}

Afriyeni, A., \& Fernos, J. (2019). Analisis Pengaruh Faktor Determinan Terhadap Economic Value Added Dan Implikasinya Terhadap Pergerakan Harga Saham Properti Di Bursa Efek Indonesia. https://doi.org/10.31219/osf.io/qf5nm

Anissa Tamba. 2012. Analisis Kinerja Keuangan dengan Menggunakan Pendekatan EVA dan MVA Pada Bank BUMN yng Go Public (studi kasus pada PT. Bank Mandiri, tbk, PT. Bank BNI, tbk dan PT. Bank BRI, tbk). Skripsi Fakultas Ekonomi Universitas Hasanuddin.

Anggoro Dwi Putra. 2014. EVA (Economic Value Added) dan MVA (Market Value Added) MVA sebagai Alat Ukur Kinerja Keuangan (Studi Pada PT.HM Sampoerna, Tbk dan PT.Gudang Garam, Tbk Periode 2011-2013). Jurnal ABFI, Tahun 2014.

Any Arisanti.2016. Analisis Perbandingan antara Metode EVA dan MVA sebagai Pengukuran Kinerja Keuangan Perusahaan (studi kasus pada Perusahaan Rokok yang terdaftar di BEI Periode Tahun 2012-2014).Jurnal Ekonomi Akuntansi : Vol.1, No.1 April 2016.

Arifin, I. Z., \& Marlius, D. (2017). Analisis Kinerja Keuangan PT. Pegadaian Cabang Ulak Karang. https://doi.org/10.31227/osf.io/n2peu

Brigham, Eugene F \& Houston, Joel F. 2006. Fundamentals of Financial Management. Tenth Edition, Yulianto, Ali Akbar (Penerjemah). 2006. DasarDasar Manajemen Keuangan. Edisi Kesepuluh, Jakarta : Salemba Empat.

Fahmi Irham, 2011. Analisis Kinerja Keuangan, Jakarta: CV. Alfabeta.

Fridayana, Luh Putu Ayu dan Ni Nyoman Yulianthini. 2014. Kinerja Keuangan menggunakan pendekatan EVA (Economic Value Added) dan MVA (Market 
Value Added) pada Bank BUMN. Jurnal Bisma Universitas Pendidikan Ganesha, Vol.4, Tahun 2016.

Gitosudarmo, Indriyo, dan Basri 2002 Manajemen Keuangan, edisi keempat, cetakan pertama, Yogyakarta : BPFE

Gulo, Wilmar Amonio, Wita Juwita Ermawati. 2011. Analisis Economic Value Added (EVA) dan Market Value Added (MVA) sebagai Alat Ukur Kinerja Keuangan PT SA. Jurnal Manajemen dan Organisasi, Vol, No.2, Agustus : 123-133.

Hanafi, M. Mamduh. 2005. Analisis Laporan Keuangan. Edisi Kedua, Yogyakarta : UPP AP YKN.

Kasmir, SE., MM. 2008, Analisis Laporan Keuangan, edisi pertama, cetakan pertama, Jakarta : Rajawali Pers.

Rahmayeli, D. S., \& Marlius, D. (2017). Analisis Kinerja Keuangan Pada PT. Bank Perkreditan Rakyat (BPR) Batang Kapas Pesisir Selatan. https://doi.org/10.31227/osf.io/sz5db

Situs Resmi http://www.bi.go.id

Situs Resmi htpp://www.idx.go.id

Situs Resmi htpp://www.sahamok.go.id

Young, S. David \& O’Byrne, Stephen F. 2011.EVA dan Manajemen Berdasarkan Nilai: Panduan PraktisUntuk Implementasi, edisi pertama, Jakarta : Salemba.

Yoga Prassetya. 2015. Analisis Perbandingan Kinerja Keuangan Antara Bank Mandiri dan Bank Rakyat Indonesia Berdasarkan Economic Value Added dan Market Value Added Pada Tahun 2011-2013. Jurnal e-preceeding ofManagement : Vol.2, No.1 April 2015. 